\begin{tabular}{lll}
\hline Ročník LIII & 2 & Ć́slo 3, 2005 \\
\hline
\end{tabular}

\title{
INTERNATIONAL PROJECT COMMUNICATING TOWN
}

\author{
M. Foret, V. Foretová
}

Received: February 11, 2005

\begin{abstract}
FORET, M., FORETOVÁ, V.: International project Communicating town. Acta univ. agric. et silvic. Mendel. Brun., 2005, LIII, No. 3, pp. 17-24

The main objectives of the project Communicating Town is to assist in an improvement of mutual relationships and communication between the council and the public. The use of opinion polls provide an opportunity for the silent majority of citizens to voice their views. The standardised interviews make it possible to get the respondents involved in communication activities. Each questionnaire had two parts; the first sought opinions on questions asked by the council in the given town and the other part was common to all the towns involved and allowed us to compare and make general conclusions. The results were presented in the press. During 1995-2000 nearly fifty towns in the Czech Republic and Slovakia participated in the project Communicating Town. The ten years of study within the framework of the project have demonstrated that this project can provide valuable contributions to many aspects of council and town policies. With each year, further towns have shown an interest in involvement in the project. The results from Brno, Loštice and Zlín, i.e., towns where opinion surveys were repeated at intervals of between one and four years, indicate that the relationships between citizens and the council have improved.
\end{abstract}

council, public, opinion poll, communication activities, evaluation of the local government

In the early 90's during our investigations of public opinion on state and local administrations in Brno and Břeclav, we noticed an interesting link between the level of information available on the council's activities and the citizens' satisfaction with the council's performance. These results were published in Foret (1994) and provided the initial material for a long-term project, called Communicating Town, which has been supported by a grant from the Open Society Fund in Prague. The concept and resources of the project and the results from 1995 were published in Foretová - Foret (1996). Our research was extended and continued in 1995 to 1996 and the results were published in 1998 Foretová - Foret - Gole (3). The results 1997 and 1998 contains the last material Foretová - Foret (1999) and Foretová - Foret (2000). During 1995-2000 nearly fifty towns in the Czech Republic and Slovakia participated in the project Communicating Town.
The main objectives of the project is to assist in an improvement of mutual relationships and communication between the council and the public, promotion of the development of civic society, and demonstrating to the public administration a way in which citizens could be involved in a variety of communal issues, from long-term strategies for town development to problems of unemployment and support of enterprise.

A town, a village or a region, is a complex, well-structured entity with various functions and services provided for different socio-economic groups of its population. Its performance can be efficient when co-ordinated in terms of action, finance and schedule. This is the responsibility of the state and local governments but is impossible to achieve without the interest, involvement, respect and tolerance of people living in that particular place. A well-informed popu- 
lation will be able to participate in the implementation of development plans proposed and worked out by the municipal representative body. The results of the international project Communicating Town demonstrated that only these citizens with an insight into the mechanisms of the function and development of a town can co-operate effectively with the local government, share responsibilities for the town's further progress and lead full and satisfied lives.

\section{MATERIALS AND METHODS}

As mentioned before, opinion surveys provide an opportunity for the silent majority of citizens to voice their views. If performed systematically, they may become a useful instrument in communication between the council and its constituents. But ascertaining opinions of citizens does not mean the council intends to subordinate all its policies to public wishes. Knowing citizens' views which reflect their everyday experience, education and level of relevant information provides the local administration with a basis for the explanation and advocacy of its plans, proposals, goals and objectives by informed communication.

Opinion polls facilitate:

- evaluation of the council's performance on the basis of objective data assessment of the appropriate wording of questions asked

- involvement of different departments in a common task

- getting into touch with citizens

- making the council's policies known

- ascertaining whether citizens understand these policies and to what extent they are informed of relevant issues

- comparison of results from different areas which permits differentiation between general and specific, local features

- better relations with massmedia

- awareness that seemingly negative results can have positive impacts on the council's activities

- acquisition of knowledge and skills which may be used later in different aspects of communication and co-operation.

The use of standardised interviews make it possible to get the respondents involved in communication activities. In the Communicating Town project, each questionnaire had two parts; the first sought opinions on questions asked by the council in the given town and the other part was common to all the towns involved and allowed us to compare and make general conclusions. The results were presented in the press. Our investigations were similar to those carried within the framework of the project EUROBAROMETER.

\section{RESULTS AND DISCUSSION \\ Results from 1997 and 1998}

In 1997, a total of 15 extensive research programmes were carried out in the Czech Republic in the framework of the Communicating Town project. Fourteen dealt with the opinions of citizens on life in their towns and one was concerned with public opinion on the region plan prepared in the town (Liberec). The towns studied fell into three size categories:

- small towns with a population of about 3000 (Lázně Bohdaneč in the Eastern Bohemia region Loštice in the Northern Moravia region),

- medium towns with a population of over thousand (Rokycany, 15 000; Šternberk, 15 000; Svitavy, 17 000; Třebíč, 40 0000)

- large towns with a population of over 100000 (Hradec Králové, 100 000; Liberec, 100 000; Plzeň, 175 000; Ostrava, 330 000).

Data were collected by a technique of standardised interview from groups of 300 to 500, in relation to town size, randomly selected citizens older than 18 years. More than 3,500 records were statistically evaluated.

In 1998, our research was carried out in co-operation with the Faculty of Economics at Matěj Bela University in Banská Bystrica in Slovakia. It consisted of eight large programmes which studied and compared citizens's opinions on council performance in both Czech and Slovak towns. These fell into three categories: small (Kremnica with a population of 6000 and Nová Ban̆a with a population of 9000$)$, medium (Frenštát pod Radhoštěm, 12 000; Kutná Hora, 22 000; Košice-Ťahanovce, 22 000; Pezinok, 22 000; Trenčín, 59 000) and large towns represented by the Slovak town of Prešov with 93000 inhabitants.

The techniques of data collection and analysis, and the selection and size of respondent samples were used in the same manner as in 1997. More than 2700 records were statistically evaluated.

The 1997 results will be dealt with in sections 1 through 5 and a comparison of results between the Czech and the Slovak Republic will be presented in section 6 .

\section{Working, business and living conditions Jobs and businesses}

An offer of jobs was reported as bad by $49 \%$, as average by $28 \%$ and as good by only $13 \%$ of the respondents in every town. The remaining $21 \%$ had no opinion.

Job opportunities were generally regarded as poor. They were strongly related to the town size and reported as good by $6 \%, 8 \%$ and $18 \%$ and as bad by $42 \%$, $29 \%$ and $21 \%$ of the respondents in small, medium and large towns, respectively. 
Conditions for private enterprises were perceived in a similar way, but $29 \%$ of the respondents were not able to give any opinion. In the whole sample, the conditions were regarded as average by $34 \%$ of the interviewed citizens. In relation to town size, conditions were reported as good by $10 \%, 18 \%$ and $24 \%$ of the respondents from small, medium and big towns, respectively.

The general response was dissatisfaction with the offer of job opportunities and low interest in chances for private enterprising.

\section{Living conditions}

The majority of respondents (57\%) think their living conditions are average, $26 \%$ consider them good and $16 \%$ bad. Only $1 \%$ of the respondents did not give their opinion.

The standard of living was perceived by $28 \%$ of the project participants as better, by $40 \%$ as unchanged and by $28 \%$ as worse compared with 1990 . This response was not related to the size of the town in which the respondents lived but to their education level. With an increasing level of education the evaluation of lifestyle was higher. On the whole, $17 \%$ of the respondents with elementary education or apprentice training, $29 \%$ of participants with secondary education and $46 \%$ of university graduates thought their standard of living was good (similarly, 17\%, 33\% and $47 \%$ of the respondents in the respective categories regarded their living conditions as better than in 1990).

Thus, town size has an effect on job possibilities and on chances for private business; the disadvantages of small towns are apparent. Living standards and socio-economic conditions are related to the level of education.

\section{Evaluation of the local government}

It was of interest to find out how the citizens evaluate various aspects of the performance of the three components of their municipal council:

A) the council administration, i.e., clerical and executive staff

B) the elected representatives and the board

C) the mayor.

In relation to each council component, opinion was sought on the respondents' satisfaction with its work, on the amount of information available on its activities, personal experience, if any, when dealing with it and the overall council image. The latter was evaluated on the basis of the following characteristics:

- professional standards (Standard)

- willingness to help and open behaviour (Openness)
- financial competence and the ability to manage communal property (Competence)

- respect for citizens' needs and wishes (Respect)

- credibility (Credibility).

Satisfaction of the citizens with each of the council levels was related to the defined criteria, i.e., the five characteristics given above, together with the level of provided information and personal experience with the council administration.

\section{A. Evaluation of the council administration Satisfaction}

More respondents were satisfied than dissatisfied (47\% against 29\%) with the performance of their council administration but $24 \%$ of them did not express an opinion. Citizens' satisfaction was indirectly related to the town size. In small towns, $83 \%$ of the respondents were satisfied while in medium and big towns this was only $45 \%$ and $41 \%$, respectively.

\section{Level of information}

The proportion of the respondents $(43 \%)$ who felt insufficiently informed about the council activities was larger than that of the citizens (34\%) who believed they had enough information. It is, therefore, in the interest of municipal authorities to increase the level of information they provide because this is closely related to the citizens' evaluation of municipal performance. From the group of sufficiently informed respondents, $69 \%$ were satisfied with their council administration performance while only $40 \%$ from the poorly informed groups were satisfied.

The degree of received information was indirectly related to town size but directly related to education level. In small, medium and large towns, 57\%, 33\% and $31 \%$ of the respondents, respectively, believed they were sufficiently informed. In groups of respondents with basic, (including apprentice) education, secondary school education or university education, $29 \%, 36 \%$ and $46 \%$, respectively, thought they were sufficiently informed about their councils' activities.

\section{Personal experience}

Less than half of the respondents (43\%) had approached the council with a request or application in any one year. Out of them, $9 \%$ went there repeatedly while $34 \%$ went only occasionally. Their personal experience, however, had less effect on their evaluation of the municipal council's performance than the level of relevant information available. In this assessment, public awareness of the council's performance was more important than direct experience with its municipal services.

From those who came into contact with the municipal authority, more $(33 \%)$ were satisfied than dissatis- 
fied (14\%). Satisfaction was more usually associated with occasional visits (in 73\%) in comparison with more frequent ones $(67 \%)$. There was more satisfaction with municipal services in small towns (51\%) than in medium $(36 \%)$ or large $(28 \%)$ towns.

\section{Image}

In order to assess the image of the council, respondents were asked their opinions on the previously defined characteristics of the staff.

This evaluation was also influenced by town size - with increasing size, it was less favourable. The degree of open behaviour and willingness to help, for instance, was regarded as above average by $36 \%$ of the respondents in small towns but only by $14 \%$ and $9 \%$ in medium and large towns, respectively.

\section{B. Evaluation of the elected representatives and the board}

Satisfaction

More respondents were satisfied (33\%) than dissatisfied $(24 \%)$ with the performance of their elected representatives and the board; this evaluation, however, was lower than that of the council administration. It was surprising that nearly half $(43 \%)$ of the respondents were not able to give any opinion. With decreasing town size, satisfaction of its citizens increased: $31 \%$ of them, respectively, were satisfied with their elected representatives in medium and large towns and $52 \%$ in small towns.

\section{Level of information}

Enough information on the elected representatives and the board was reported by $44 \%$ and not enough by $26 \%$ of the respondents. This was worse than in the case of the council and there were also more respondents who did not know or were not interested. The level of information is directly related to citizen's satisfaction with their municipal authorities - the better information, the greater satisfaction. Out of the well informed citizens, $67 \%$ were satisfied as against $28 \%$ of respondents from the poorly informed category.

The overall level of information was influenced by town size and citizens' education. Respondents with a low level of education felt they were poorly informed $(2 \%)$, those with secondary and university education reported enough information in $25 \%$ and $36 \%$, respectively.

\section{Image}

Many of the respondents either could not give an opinion or they regarded their representatives' qualities as average. In comparison with the image of the council staff, this level of the council scored low.

It appears that citizens appreciate the openness and willingness of the elected representatives more than their professional standards and respect for citizen's needs. The least important aspect, in contrast to the municipal staff, was found to be the level of information available on the activities of the representatives and the board.

\section{Evaluation of the mayor \\ Satisfaction}

The mayor's performance was found satisfactory by $53 \%$ and unsatisfactory by $25 \%$ of the respondents; $22 \%$ were not able to give their opinion. Satisfaction was again related to town size, with $85 \%$ of citizens being satisfied in small towns and 54\% and $47 \%$ in medium and large towns, respectively.

\section{Level of information}

When citizens were well informed about the activities of their mayor, they were more satisfied with his/her performance in the office than those who lacked this information ( $80 \%$ as against $45 \%$ ). Of all the respondents, $46 \%$ felt they were sufficiently informed while $34 \%$ did not.

The level of education and size of the town in which respondents lived were related to the level of information about their mayor. In small, medium and large towns, the proportions of sufficiently informed citizens were $57 \%, 33 \%$ and $31 \%$, respectively. When related to education, the values were $27 \%, 38 \%$ and $44 \%$ for subjects with basic, secondary and university education, respectively.

\section{Image}

From the three levels of municipal authorities, the mayor gained the highest appraisal. His/her most highly appreciated characteristic was professional standard.

Town size plays a role in the results of mayors' evaluation. The larger the town, the lower the score. For instance, mayor's respect for citizens' wishes and needs was assessed as ,above the average“ by $54 \%$, $18 \%$ and $14 \%$ of the respondents from small, medium and large towns, respectively.

The most important factors in a positive evaluation of the mayor was his/her professional standard and the respect for citizens' wishes and needs. Less important was the degree of information available to the citizens on the mayor's performance.

\section{Conclusion}

Satisfaction of the respondents is related to the provision of sufficient information on the activities of local, or state, administration, to the fact that the elected representatives are obliging and open to their problems and that the mayor has an authority based on his professional standard. In all three levels, (council, elected representatives and board, mayor), the most 
difficult characteristics to obtain response to appeared to be financial competence and the ability to manage communal property.

\section{Differences among towns}

The situation, related to citizens' satisfaction with the council and their information on its activities, was better in small towns than in medium and large ones. The Communicating Town project showed that, generally, the latter should receive more attention in terms of their communication with the public.

The results obtained in the ten towns involved in the Communicating Town project, i.e., towns which have received special attention for some time, however, do not necessarily, provide a representative picture of all the towns in the Czech Republic. To take part in the project required interest, activity and, to some extent, even courage from the councils because it meant they would learn their population's opinion of their performance. It can be expected that the general situation would be worse.

\section{Comparison between Czech and British towns}

Based on the results of research carried out in the Czech Republic in 1997 and the relevant data collected in the same year in Ipswich, Great Britain, we were able to make some comparisons on the international level. The Czech towns and Ipswich are comparable in terms of size and the role in regional administration. In all towns, the same method of data collection (i.e., standardised interview) was used and included 585 persons, 16 years and older, selected by quota sampling in Ipswich and about 500 persons, 18 years and older, randomly selected in each Czech town.

About the same proportion of the respondents (more than one quarter) in the two countries were not able to give an opinion. The differences between satisfaction and dissatisfaction, however, were considerable. In Ipswich, about $70 \%$ of the respondents were satisfied with their council's performance, in the Czech towns this was only $40 \%$. Very few respondents (4\%) were dissatisfied in Ipswich while, in the Czech republic, $34 \%$ were dissatisfied.

\section{Ipswich council's performance}

The good response from the Ipswich respondents can be ascribed to the following factors.

1) The council cares for the town using the available funds in the most efficient way. The results of its audits are amongst the best in Great Britain and the Council has received several awards which were appropriately medialised.

2) For a long time, the council has paid attention to communication with the citizens. It regards them as its customers and, using a marketing approach, it strives to provide good services. The commu- nication with the public has various forms and is taken as a matter of fact rather than deliberate effort. All municipal bodies are interrelated and open to insiders as well as outsiders.

The citizens' relationship to the town has developed with reference to the previous generations' achievements and emphasis on their share in responsibilities for their town development. Heritage, the word linking the present with the past, whether historical buildings or traditions are involved, has a much broader meaning than formal reference to history.

The council disseminates relevant information plentifully and provides a lot of opportunity for the citizens to comment, criticise or influence its policy. It is worth mentioning that opinion surveys dealing with community issues are presented in connection with various forms of contests or competitions and awards (theatre tickets, swimming pool entrance fees, etc.) are provided by the municipal bodies involved.

For more than 10 years, each family has received a free-of-charge monthly journal, called The Angle. We present this newsletter as an example of an efficient and informative council publication at our courses on public relations in towns and villages.

The high evaluation of the Ipswich council also results from other activities, such as unemployment issues and creation of new jobs. One of the latter is the case of the local brewery. This is one of the historical buildings with a long tradition and interesting history. However, it has recently stopped being prosperous. Therefore, the council included it in a sight-seeing tour of Ipswich. During an excursion, visitors can learn everything about beer making and its history and, in a special education programme designed for economy students, get to know why and how the brewery found itself in this difficult situation. As a result, the brewery still functions, though to a limited extent, and provides jobs for some workers, restaurant employees, guides and beer brewery lecturers.

More than half $(56 \%)$ of the respondents thought the Ipswich council should make promotion of business and employment its priority. Only $26 \%$ believed that the council should be more caring about the environment and its protection. A desire for more careful management of communal property and more interest in providing leisure time facilities was expressed by $18 \%$ of the respondents to each issue. The Ipswich council operates indoor swimming pools, concert and assembly halls and museums are free.

\section{Job opportunities}

In the Czech Republic, creation of jobs and promotion of business activities are issues which, in the opinion of our respondents, should receive more attention from town councils. A total of $40 \%$ of the respondents thought that the offer of job opportunities was 
poor and that councils should become more involved. Opportunities for private enterprise were considered bad by $16 \%$ and $30 \%$ of the respondents were not interested in this issue.

The Ipswich council carried out a survey to find out the reasons preventing the unemployed from obtaining a job.

The most frequent responses from women were:

- lack of facilities for pre-school children care $28 \%$

- high prices of services associated with care for small children $-27 \%$

- low level of education $-13 \%$.

Men gave the following most frequent reasons:

- high age $-23 \%$

- poor health, disability to work $-23 \%$

- low level of qualification - 13\%

- insufficient experience $-13 \%$.

The most frequent reasons for job loss given by female respondents were pregnancy and care for infants $(50 \%)$ and those reported by male respondents were cutting of jobs $(27 \%)$ or injury or illness $(23 \%)$.

\section{Specific findings}

The interview section allowing the councils to seek citizens' opinion on specific or ,"hot" issues in each town investigated provided the following results:

\section{a) Development in Loštice}

A comparison of two opinion surveys carried out within two years showed that the citizen's satisfaction with the council's performance increased while their positive evaluation of the elected bodies decreased considerably, by almost $20 \%$, or they had no opinion. These responses were reflected in a progressive loss of respect for the elected representatives but a growing appreciation of the work of the council staff.

\section{b) Contribution of the negative results}

In Třebíč, the specific question was aimed at finding out how many families owned personal computers because the council had planned to use these for communication with the citizens. The finding that only a small proportion of the population $(23 \%)$ had this facility made it apparent that the time for this communication instrument has not come yet.

\section{c) Importance of unique sports events}

Uncommon sports events play an important role in creating the town's image, distinguishing it from many other similar towns and promoting enterprise and tourist business.
Our survey in Šternberk, for instance, showed that its citizens support and appreciate the European Championship automobile rally which takes place in their town; $87 \%$ of the respondents believe that this event, known as Ecce Homo race, is a contribution for the town. The respondent categories which most frequently held this view were employed persons, university graduates and men.

In Liberec, citizens were asked their opinion on the World Championship in classical skiing disciplines to be held in the Liberec-Jablonec mountain region in 2003. About two thirds of the respondents (64\%) were convinced that this event would positively influence the development of the town. This was mostly the opinion of university graduates, private entrepreneurs and young people (18 to 24 years).

\section{d) Citizens'opinion on investment plans of the coun- cil}

In Hradec Králové, the public opinion survey concerning the building of large supermarkets showed what a variety of materials for decision making could be obtained.

A further development of the present supermarket near Gumokov factory, which is regularly visited by $15 \%$ and occasionally by $45 \%$ of citizens, was supported by $65 \%$ of the respondents. On the other hand, only $37 \%$ of the respondents approved of the building of the Magnum supermarket in one of the suburbs while $34 \%$ were against it. In giving the reasons for this building activity, the council, therefore, should use public relations instruments to explain and justify its intentions.

\section{e) Retrospective evaluation of major town invest- \\ ments}

In some instances, the town representatives have made a decision on an extensive investment without previous seeking for citizens' views on the issue. Our investigations were concerned with ascertaining what the citizens thought about the given issue afterwards.

Two medium-size towns were selected. In Svitavy, a complete reconstruction of the main square was made. This increased the attractiveness of the place and made its citizens like their town better and be proud of it. Our surveys showed that only $4 \%$ of the respondents thought the reconstruction to be unnecessary while $92 \%$ considered it an improvement. This positive view was held by many young people, 18 to 24 years old, living in the town.

In Třebíč, the council began to renovate historical buildings, including the old Jewish ghetto which is largest in the Czech Republic. Although completion of this project will require very high investment costs, the citizens realise the importance and future contribution of this action, as shown by $92 \%$ of the respondents, who supported this investment. 


\section{f) Citizens' interest in town development activities}

It is known that citizens are generally not interested in taking part in the preparation of administrative policies, such as community budget proposals, development plans, etc. The council in Hradec Králové used our investigation to learn if the citizens would come to a public meeting dealing with the creation of strategies for further development of the town. Only 40\% of the respondents gave an affirmative response; of these $53 \%$ were university graduates and only $25 \%$ were young people between 18 and 24 years.

In Ostrava, only one third of the respondents were interested in the organisation and administration of their town. They mostly belonged to one of three categories: university graduates $(57 \%)$, private entrepreneurs (58\%) and middle-aged citizens (43\%).

In Liberec, our research revealed that participation of citizens in communal policy is directly related to the level of their education. In a special survey we asked the citizens about their views on the proposed town master plan. It appeared that $80 \%$ of the respondents would like to know more about the plan. However, only $60 \%$ of these were prepared to contribute with comments and only $20 \%$ would take active an part in its preparation. The more active participation was offered, the less interest was shown. In all questions asked, university graduates, private entrepreneurs and the middle-aged generation (35 to 59 years) showed more interest.

\section{g) Criminal and racial issues}

In Rokycany, we asked to what extent citizens felt jeopardised by growing criminality and whether they were aware of the existence of racism. The citizens who did not feel in danger were twice as many (62\%) as those who were afraid, and $70 \%$ did not believe in the existence of racial problems in the town. The citizens did not relate increase in the crime rate to the manifestation of racism.

In this special survey concerning criminality, we asked the Rokycany citizens which population group presents the greatest threat to them. The choice offered did not include the Roma (Gypsies) as a category of risk-related citizens. These were listed under the general category of „others“ which was reported as the most frequent threat to citizens' safety by three quarters of the respondents. The ,others“ category as a whole was most frequently regarded as dangerous ( $28 \%$ of the respondents), recidivists were feared by $21 \%$, thieves by $19 \%$ and extremists and skinheads by $16 \%$ of the respondents.

\section{Comparison with the Slovak Republic}

The level of information available to citizens does not always play a major role in their satisfaction with the performance of their local government, i.e., administrative staff, elected representatives and mayor.
The highest level of satisfaction was found in Frenštát pod Radhoštěm, where more than half of the population was satisfied and only one third had no opinion. In this town, half of the respondents felt they had enough information on the councils' activities. About $75 \%$ believed that the local television programme was the best source of information about both the council's activities and events in the town. The regular council newsletter was regarded as the best source of information by only $16 \%$ of the respondents. The degree of satisfaction was found to be related to age and education. Citizens of middle age, those with university education and employed people were satisfied while young respondents, between 18 and 24, were not satisfied.

In Prešov, a large Slovak town, only one third of the respondents were satisfied with the activities of the municipal staff. In the year 1998, however, less than one half of total number of respondents had any official experience with the council administration. No interest in the town council was reported by $41 \%$ of the group of respondents mainly covering citizens with lower education and women. Monthly publication of a council bulletin would be appreciated by $83 \%$ of the Prešov population, $10 \%$ were not interested and the rest had no opinion.

Citizens' satisfaction with the performance of the mayor was always higher than that of the elected representatives and the board. The highest satisfaction was recorded in Nova Ban̆a (71\%), a small Slovak town.

In relation to elected bodies, people were usually more satisfied with the performance of representatives than with that of their board.

Despite a high degree of satisfaction with the elected bodies in Košice-Ťahanovce, a large proportion of its citizens believed that corruption in the municipal council and town offices was a wide-spread phenomenon unfavourably affecting town development. A better situation was recorded in Kutná Hora, Pezinok, Trenčín and Nova Baňa.

The improvement in living conditions during the past election period (1994 to 1998) was highly appreciated by the respondents from Pezinok. Citizens between 25 and 34, university graduates, private entrepreneurs and women frequently regarded recent living conditions as being improved while young citizens, workers and men often felt that the conditions remained unchanged. In an open question the respondents were invited to comment on specific improvements. A considerable proportion of the respondents appreciated the council's care for their town's appearance, including green areas and reconstruction of old buildings, and the extension of business network. Some respondents, however, felt that the town was deteriorating, the business network was not sufficient, 
services had a low standard and there were not enough of them, and that the council's financial policy was not transparent.

In this comparison, the results in Slovak towns showed that the influence of town size, citizens' age and education, and the level of available information were equally important for the evaluation of local governments as they were in the Czech Republic.

\section{SUMMARY}

The ten years of study within the framework of the Communicating Town project have demonstrated that this project can provide valuable contributions to many aspects of council and town policies. With each year, further towns have shown an interest in involvement in the project. The results from Brno, Loštice and Zlín, i.e., towns where opinion surveys were repeated at intervals of between one and four years, indicate that the relationships between citizens and the council have improved. This does not necessarily imply that the improved situation was exclusively due to these towns being involved in the Communicating Town project. It is more likely that the improvement could be attributed to the emphasis placed on communication between the council and the public. Local governments can develop this communication using the instruments and information provided at meetings and seminars convened by the authors.

\section{SOUHRN}

\section{Mezinárodní projekt Komunikující město}

Hlavním cílem mezinárodního projektu Komunikující město bylo zlepšení vztahů a komunikace mezi radnicí a veřejností. Využitím výzkumů veřejného mínění byla "mlčící většině” občanů dána příležitost vyjádřit svůj názor. Standardizované rozhovory jim umožnily se zapojit do komunikačních aktivit. Každý záznamový arch se skládal ze dvou částí, v první byly specifické otázky, které zajímaly představitele konkrétního města, ve druhé byly naopak stejné otázky pro všechna města. Tím bylo možné v projektu zúčastněná města navzájem porovnávat a zevšeobecňovat zjištěné poznatky. Výsledky byly publikovány v místním tisku. Během let 1995-2000 se projektu zúčastnilo téměř padesát měst z České republiky i Slovenské republiky. Desetileté zkušenosti s tímto projektem přispěly ke zlepšení činnost radnic. Každoročně o účast v něm projevovala nová a nová města. Výsledky z Brna, Loštic a Zlína, kde se výzkumu veřejného mínění po několika letech opakovaly, potvrdily zlepšení vztahů mezi radnicemi a občany.

radnice, veřejnost, výzkum veřejného mínění, komunikační aktivity, hodnocení místní správy a samosprávy

\section{REFERENCES}

FORET, M.: Komunikace s veřejností. 1. vyd. Brno: Masarykova univerzita v Brně, 1994. 200 s. ISBN 80-210-1034-7

FORETOVÁ, V., FORET, M.: Komunikující město.

1. vyd.: Masarykova univerzita v Brně, 1996. 107

s. ISBN 80-210-1287-0

FORETOVÁ,V., FORET, M., GOLE, J. S.: Commu- nicating Town. First edition Brno: Masaryk University, 1998, 70 s. ISBN 80-210-1730-9

FORETOVÁ,V., FORET, M.: Communicating Town and Regional Development. First edition Brno: Masaryk University, 1999, 48 s. ISBN 80-210-2182-9

FORETOVÁ, V., FORET, M.: The Council and the Public. Occasional Papers in Public Administrartion and Public Policy, Spring 2000, vol. I, no 2, pp. 3-29, ISSN 1335-5945

\section{Address}

Prof. PhDr. Miroslav Foret, CSc., Ústav marketingu a obchodu, Mendelova zemědělská a lesnická univerzita v Brně, Zemědělská 1, 61300 Brno, Česká republika, e-mail: foret@mendelu.cz 